\title{
Prenatal diagnosis of persistent cloaca accompanied by uterus didelphys: A case report
}

\author{
Uterus didelphys'ye esslik eden persistan kloakanın prenatal \\ tanisi: Bir olgu sunumu
}

\author{
(1) Koray Görkem Saçıntı, (1) Gizem Oruç, (1) Erdal Şeker, (1) Mehmet Seçkin Özışık \\ Ankara University Faculty of Medicine, Department of Obstetrics and Gynecology, Ankara, Turkey
}

\begin{abstract}
Persistent cloaca is a rare abnormality that occurs usually in females and is characterized by direct communication between the gastrointestinal, urinary, and genital structures resulting in a single perineal opening. We report a case of persistent cloaca accompanying uterus didelphys that was diagnosed antenatally with fetal ultrasonography. A gravida 3, para 2, 35-year-old women at 22 weeks of gestation was referred to our hospital with a diagnosis of moderate pyelectasis of the fetal kidneys and fetal diffuse intestinal dilation. Detailed ultrasound scan findings were reported as a small thick-walled septated cystic pelvic mass of $5.2 \times 5.5 \mathrm{~cm}$ size seen at the level of the fetal pelvic region. The target sign could not be visualized, it was considered as anal atresia. In the following weeks, the patient, who was evaluated together with meconium on the uterine septum, and monitoring of the neighboring bladder and anal atresia, was diagnosed as having persistent cloaca. Ultrasound findings showed that it could be persistent cloaca accompanying uterus didelphys. The fetus postnatally manifested persistent cloaca. On the first day after vaginal delivery, pelvic ultrasound in the neonatal intensive care unit showed bilateral $2^{\text {nd }}$-degree hydronephrosis, presacral enlarged bowel loops, uterus didelphis, vaginal septum, direct contact between urethra and vagina, proximal end in the rectum compatible with atresia. On the second day, colostomy was performed. Her renal condition continued to be stable. She is now waiting for definitive surgery for cloaca. Persistent cloaca should be considered in any female fetus presenting with hydronephrosis and a cystic pelvic mass lesion as diagnosed by ultrasound. Prenatal diagnosis allows time for parental counseling and delivery planning at a tertiary hospital for neonatal intensive care and pediatric surgery
\end{abstract}

Keywords: Persistent cloaca, uterus didelphys, prenatal diagnosis, fetal pelvic mass

$\mathrm{O} z$

Persistan kloaka, genellikle kadınlarda görülen; gastrointestinal, üriner ve genital yapılar arasında doğrudan tek bir perineal açılklkla karakterize nadir görülen bir anomalidir. Fetal ultrasonografi ile antenatal olarak tanı konulan uterin didelfisin eşlik ettiği bir persistan kloaka olgusunu sunuyoruz. Otuz beş yaşında kadın, gravida 3, para 2, fetal böbreklerde orta derecede piyelektazi ve fetal diffüz intestinal dilatasyonu olan 22 hafta gebelik tanısıyla hastanemize sevk edildi. Detaylı ultrason taraması bulguları, fetal pelvik bölge seviyesinde $5,2 \times 5,5 \mathrm{~cm}$ boyutlarında küçük kalın duvarlı septasyonlu kistik pelvik kitle olarak rapor edildi. "Target sign" görüntülenemedi, anal atrezi olarak değerlendirildi. İlerleyen haftalarda uterin septumda mekonyum görülmesi, komşuluğunda mesanenin izlenmesi ve anal atrezisi olan hastaya persistan kloaka tanısı konuldu. Ultrason bulguları, uterin didelfisin de eşlik ettiğini gösterdi. Vajinal doğumdan sonrası persistan kloaka gösterildi, yenidoğan yoğun bakım ünitesinde yapılan pelvik ultrasonda bilateral 2. derece hidronefroz, presakral diffüz intestinal segmenti, uterus didelfis, vajinal septum, üretra ve vajina arasında direkt temas, rektumda proksimal uç atrezisi raporlandı. İkinci gün kolostomi açıldı. Renal durumu stabil devam eden hasta şimdi kloaka için cerrahisi bekliyor. Ultrason ile tanı konulmuş kistik pelvik kitle ve hidronefroz ile gelen her kız fetüste persistan kloaka düşünülmelidir. Prenatal tanı, yenidoğan yoğun bakım ve çocuk cerrahi olan üçüncü basamak bir hastanede ebeveyn danışmanlı̆̆ı ve doğum planlaması için zaman sağlar.

Anahtar Kelimeler: Persistan kloaka, uterus didelfis, prenatal tanı, fetal pelvik kitle

\section{Introduction}

Cloacal anomalies represent the persistence of early embryonic development in which the urinary, genital, and gastrointestinal tracts remain confluent and communicate with the exterior through a single perineal opening. It is an extremely rare disorder, the incidence being 1 in 50,000 births ${ }^{(1)}$. It generally affects females. There may be co-existent anomalies of the gastrointestinal tract, cardiac, renal, uterine, skeletal and limbs. The presence of a cloaca is a normal phase of early human embryologic development. Between the $4^{\text {th }}$ and $7^{\text {th }}$ weeks

Address for Correspondence/Yazışma Adresi: Koray Görkem Saçıntı MD,

Ankara University Faculty of Medicine, Department of Obstetrics and Gynecology, Ankara, Turkey

Phone: +90 5073963086 E-mail: mail@koraygorkemsacinti.com ORCID ID: orcid.org/0000-0002-8602-9714

Received/Geliș Tarihi: 23.10.2020 Accepted/Kabul Tarihi: 29.11.2020

${ }^{\oplus}$ Copyright 2021 by Turkish Society of Obstetrics and Gynecology

Turkish Journal of Obstetrics and Gynecology published by Galenos Publishing House. 
of gestation, the cloaca undergoes subdivision to form the hindgut and urogenital sinus. Failure of this process results in the congenital anomaly termed persistent cloaca $^{(2)}$. Herein, we report a case of persistent cloaca accompanying uterus didelphys that was diagnosed antenatally in fetal ultrasonography.

\section{Case Report}

A gravida 3, para 2, 35-year-old woman at 22 weeks of gestation was referred to our hospital with a diagnosis of moderate pyelectasis of the fetal kidneys and fetal diffuse intestinal dilation. The amniotic fluid level was normal. Detailed ultrasound scan findings were reported as a small thick-walled septated cystic pelvic mass of $5.2 \times 5.5 \mathrm{~cm}$ size seen at the level of the fetal pelvic region. Except for two previous normal vaginal deliveries, her obstetric history was unremarkable. The glucose tolerance test performed at about 24 weeks during pregnancy led to the diagnosis of gestational diabetes. The target sign could not be visualized, and anal atresia was considered. In the following weeks, the patient, who was evaluated together with meconium on the uterine septum, and monitoring of the neighboring bladder and anal atresia, was diagnosed as having persistent cloaca (Figure 1). She was diagnosed as having intrahepatic cholestasis of pregnancy at 37 weeks of gestation. We decided to induce labor as determined by the Bishop score. After the initiation of misoprostol induction, in another $8 \mathrm{~h}$, the patient gave birth to a live-born female infant weighing 2,520 g, a height of $47 \mathrm{~cm}$, and an Apgar score of 9-10 points. The female neonate presented with an absent anal opening; she was passing stool from the vestibule. The newborn had abdominal distension, simulating a distended bladder, and rectal atresia with a single perineal opening between the labia majora. The fetus postnatally manifested as persistent cloaca. On the first day after vaginal delivery, pelvic ultrasound in the neonatal intensive care unit showed bilateral $2^{\text {nd }}$-degree hydronephrosis, presacral enlarged bowel loops, uterus didelphis, vaginal septum, direct contact between urethra and vagina, and the proximal end in the rectum was compatible with atresia. On the second day, colostomy and cystoscopy were performed. Her renal condition continued to be stable. She is now waiting for definitive surgery for cloaca. The patient postpartum period was uncomplicated. At the follow-up visit between 4-6 weeks, the patient was in good health and without symptoms.

\section{Discussion}

Persistent cloaca is an uncommon malformation that generally occurs in females, with a reported incidence of $1: 50,000^{(1)}$. It is a complex anomaly with a confluence of the rectum, vagina, and urethra into a single common channel, and can be associated with female hypospadias, duplex uteri, bladder diverticulum, and double vagina, to more complex anomalies ${ }^{(3)}$.

Cloacal anomalies are considered prenatally in the presence of bilateral hydronephrosis, a pelvic cystic lesion, and a poorly visualized bladder ${ }^{(1)}$. However, prenatal diagnoses of female urogenital anomalies are usually difficult. Accurate diagnosis and classification of cloacal anomalies during pregnancy are essential to predict perinatal morbidity and mortality. These defects are rare, manifest as varying defects, and particularly in the late stages of pregnancy, lack characteristic ultrasound $\operatorname{signs}^{(4)}$

In our case, the cloacal anomaly presented as a fetal duplication cyst. The fetal pelvic septated cyst that raised clinical suspicion confirmed on the postnatal period as uterine duplication with hydrometrocolpos. Most cases of cloacal anomaly have been reported to be associated with fetal ascites ${ }^{(5)}$. Fetal urine drains through the fallopian tube to the peritoneal cavity and this process causes a chemical reaction that determines the tubal obstruction, hydrocolpos, and resolution of ascites, but in our case, no ascites was observed. Fetal magnetic resonance imaging (MRI) is an important diagnostic imaging adjunct to ultrasonography, particularly for the initial diagnosis of cloacal malformation $^{(6)}$. Ultrasonography or fetal MRI can identify large cystic pelvic masses, but their origin cannot be determined in most cases.

\section{Conclusion}

Persistent cloaca can be diagnosed prenatally and should be considered in any female fetus presenting with hydronephrosis

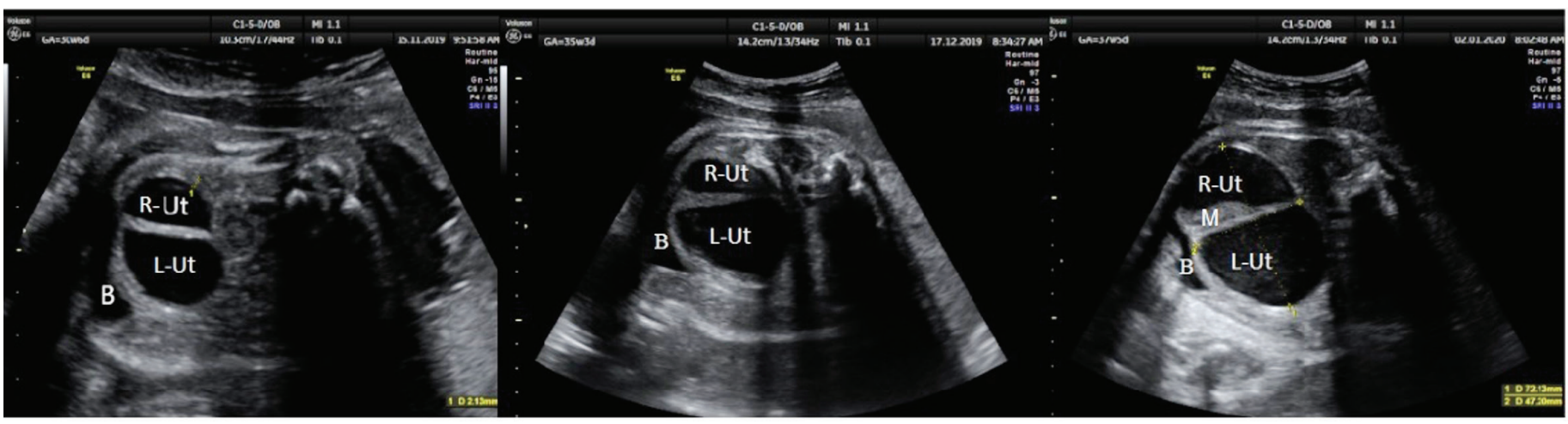

Figure 1. Ultrasound images show the evolution of cloaca accompanied uterus didelphys from 30, 35 and 37 weeks of gestation respectively R-Ut: The right uterine cavity, L-Ut: The left uterine cavity, B: Bladder, M: Meconium 
and a large cystic lesion arising from the pelvis as assessed by ultrasound. Prenatal diagnosis allows time for parental counseling and delivery planning at a tertiary hospital for neonatal intensive care and pediatric surgery. A cystic pelvic mass in any female fetus should be evaluated for cloacal anomalies.

\section{Ethics}

Informed Consent: The patient has given their informed consent for the case report to be published.

Peer-review: Externally and internally peer-reviewed.

\section{Authorship Contributions}

Surgical and Medical Practices: E.S., M.S.Ö., Concept: G.O., E.Ş., Design: G.O., M.S.Ö., Data Collection or Processing: K.G.S., G.O., Analysis or Interpretation: K.G.S., E.Ş., Literature Search: K.G.S., Writing: K.G.S.

Conflict of Interest: The authors declare no conflict of interest. Financial Disclosure: The authors declared that this study received no financial support.

\section{References}

1. Warne S, Chitty LS, Wilcox DT. Prenatal diagnosis of cloacal anomalies. BJU Int 2002;89:78-81.

2. Thomas DFM. The embryology of persistent cloaca and urogenital sinus malformations. Asian J Androl 2020;22:124-8.

3. Desai J, Mehta A, Patel P, Chavda VA. Critical Case Report-Cloacal Malformation: Prenatal Diagnosis and Autopsy Findings. Austin J Surg 2019;6:1162.

4. Odibo AO, Turner GW, Borgida AF, Rodis JF, Campbell WA. Late prenatal ultrasound features of hydrometrocolpos secondary to cloacal anomaly: case reports and review of the literature. Ultrasound Obstet Gynecol 1997;9:419-21.

5. Hamada T, Hirose R, Kosaka T, Taniguchi K, Noguchi M, Kihara $\mathrm{T}$, et al. Giant cystic meconium peritonitis associated with a cloacal anomaly: case report. J Pediatr Surg 2008;43:21-3.

6. Sahinoglu Z, Cerrah Celayir A, Resit Asoglu M, Özcan N. Diagnostic difficulties in a case of persistent cloaca with hydrocolpos. J Neonatal Surg 2012;1:55 